\title{
Rechtsgeschichte
}

\section{Anthony Carty}

Between Despair and Parody 


\section{Between Despair and Parody*}

This ambitious work has to be seen as much more than a history of doctrine in international law. Koskenniemi has been, for some time, very troubled by the increasing turn to a technical pragmatism in the profession of international lawyers. Since 1945 and especially since the I960s the profession has offered no vision to influence a wider international society. The time span which Koskenniemi gives himself for this judgement is limited to the period between the founding of the Institute of International Law in I 873 and, possibly, the US intervention/invasion of the Dominican Republic in 1965.

The book has to be understood above all as an internal critique of the profession of international lawyers. Basing himself upon professional journal reviews and obituaries, as well as the writings, sometimes previously unpublished, of the lawyers, Koskenniemi paints a picture of a profession which is, at best, well meaning but very average in ability and unable to rise above and make a distinct mark upon the times. The author's remarkable grasp of the intellectual and cultural background in which the lawyers worked illustrates this fact most convincingly.

The profession preaches the values of liberalism, a secular humanism, appeals to public conscience, tolerance and rationality. This should replace brute force and strength in interstate relations with rational negotiation, agreement and peaceful settlement of disputes through mediation or third party adjudication. These are the modest instruments of an essentially middle class profession which has to face the crises of capitalism, imperialism, extreme nationalism, racism, the coming of the ages of mass media, industrialization and democracy. No one could be sharper than Koskenniemi himself in demonstrating the shallowness and contradictions of the lawyers he describes. In particular the duel in inter-war France between Scelle and Le Fur shows how entangled in contemporary quarrels of »left " and » right " the lawyers were and how little they could rise above their times. In particular Koskenniemi makes heavy weather of how compromised European liberal culture, and also its legal expression, was in the turn of the century colonial and imperial enterprise in Afri$\mathrm{ca}$. There is a masterly exposition of the history of international law doctrine, especially in the French language, in relation to the Congo.

What adds poignancy to Koskenniemi's style and to the literary quality of his work is the fact that he fully sympathizes with the views of his protagonists, despite their weaknesses. $\mathrm{He}$ is gentle himself in his often ironical criticism as he shares the profession's sense of powerlessness to resist the elements of illiberal irrationalism and brute force which then, as now, dominate international society. There is almost tragic comedy in his description of the otherworldly reflections of Erich Kaufmann in Hitler's Germany in the late I930s. Kaufmann's transition from Neo-Hegelianism to a form of Platonism is a picture of a "world of yesterday « (Stefan Zweig's, Die Welt von Gestern). At this time Koskenniemi has no interest in the illiberal spirits of Verdross and Schmitt, who are compromised by the brutality of their times. Kaufmann, traditionally a right wing nationalist, but driven into exile because of his Jewish religion, offers a perfect example of the idealist devoted to a vision of international society, however little his talents and insights might be sought after

\footnotetext{
* Martti Koskenniemi,

The Gentle Civilizer of Nations.

The Rise and Fall of International

Law I 870-I960, Cambridge:

Cambridge University Press 200I, xiv, 569 p., ISBN 0-52I-623I-II
} 
by the powers around him. In a manner of speaking Koskenniemi ends his story with Wolfgang Friedmann's despairing fury at the US invasion of the Dominican Republic in 1965. Friedmann was shortly afterwards murdered on his way to work at Columbia Law School in New York. Koskenniemi's writing negotiates a fine line between despair and parody.

Many people will read, or have read, Koskenniemi's huge text for very different reasons. For my own part, impatient with the scribbling of our profession, I am attracted especially to the last two chapters that treat of the giant achievements of Hersch Lauterpacht, Carl Schmitt and Hans Morgenthau. One might quibble that Lauterpacht is not the only or even the most important English international lawyer. One might wonder why Schmitt is treated firmly within American jurisprudence, or why Morgenthau enjoys center stage among US international lawyers. In fact the last two chapters of the book abandon, to a considerable degree, the comprehensive institutional history of the profession up to the 1930 in favor of a rather profound debate about the main ideas of the period. The three figures are allowed to round up the liberal phase of international legal history. At the same time this part of the book encompasses his most original historical research as Koskenniemi delves into numerous private and unpublished papers of Lauterpacht and Morgenthau.

Here again Koskenniemi's own role and position are intriguing. He is clearly most impressed by the "anti-liberals « Schmitt and Morgenthau. They are, in a manner of speaking, allowed the last word. Lauterpacht is presented very sympathetically as a Herculean figure who has constructed most of what is positive in the contemporary English language approach to international law - the development of human rights law and judicial settlement of disputes. However, Koskenniemi exposes, in Lauterpacht's case, the inevitable drift to a technical pragmatism in an approach that, beneath a veneer of natural law, lacks any compelling philosophical or anthropological foundation.

Instead, Koskenniemi devotes his real intellectual admiration to the two great irrationalists, possibly the most powerful intellects to have wandered into and out of the profession of international law in the 2oth century. Schmitt clearly exposes the tendency of the paradigm of Empire to replace that of a Balance of Power of relatively equal States in international society. Surely this is the simple ground of the crisis which at present faces international law? Morgenthau exposes, in Freudian terms, the human irrationalism that stands in the way of appeals to conscience. At the same time Morgenthau deplores the supposedly universalist, self-indulgent, legalistic moralizing that goes with Empire.

Placed alongside the sympathetic but deeply critical exposition of Lauterpacht's espousal of human rights law and judicial settlement of disputes, this review of the foundation and conduct of Empire provides a profound review of the theoretical problems which face the system of international law at present.

One might conclude briefly by mentioning glimpses of how Koskenniemi could take the discipline forward himself. His response to the demands of Empire is to recommend what appears to be a "left-Hegelianism " under the cover of a culture of formalism. Legal argument must account for the dependency of every particularity on a universality that defines it and constitutes the ground from which it may experience itself as unfulfilled. The ability to articulate a lack in universal terms is what the culture of formalism is about. The absence of what a 
particularity feels it should possess, e.g. the right to self-determination, requires it to focus upon the universal aspect of that right. So, the decolonized does not seek to turn the instruments of its colonial masters against them. Instead, it seeks to articulate the lack of security it experienced under colonial rule as the universal violation committed by its former ruler and make the eradication of that lack the principle of its future rule (505-507). Perhaps these last difficult passages suggest a way out of the impasse of technical pragmatism. Koskenniemi's is clearly only one philosophical path to the renewal of international law. Yet it suggests that the future of the profession is far from decided. Rumors of its death are exaggerated.

Anthony Carty

\section{Besondere körperliche Merkmale}

Kaum auf dem Markt, hatte Simon Coles Buch Suspect Identities* schon einigen Wirbel verursacht. Cole, in Harvard in Science and Technology Studies promoviert, beschäftigt sich mit der Geschichte des Fingerabdrucks und anderer Identifizierungsverfahren. Sein Buch schildert die Revolution der Kriminaltechnik ab der Mitte des I9. Jahrhunderts und endet in der Gegenwart: Auf die Begeisterung für die Polizeifotografie folgen Versuche mit dem Fingerabdruckverfahren (Daktyloskopie) sowie der »anthropometrischen Bertillonage «, die eine Person anhand ihrer Knochenlängen und anderer körperlicher Merkmale identifizieren wollte. Aus der Konkurrenz und Koexistenz geht schließlich das Fingerabdruckverfahren ob seiner Einfachheit in der Datenerhebung und -archivierung als eindeutiger Sieger hervor. Mittlerweile wird es zunehmend vom genetischen Fingerabdruck ergänzt, der eine historisch nie dagewesene Zuverlässigkeit bietet, aber als forensisches Beweismittel verblüffend ähnliche Strukturprobleme in sich birgt.

Als gewiefter Wissenschaftshistoriker erzählt Cole natürlich keine geradlinige Erfolgs- geschichte. Schon die Durchsetzung der jeweiligen Verfahren in den verschiedenen Epochen resultierte nicht aus "Notwendigkeiten « oder gar deren »objektiver Überlegenheit «. Doch nicht diese Herangehensweise provozierte einige Leser, es waren vielmehr einige wohlgesetzte kritische Anmerkungen über die Fehlleistungen des Fingerabdruckverfahrens, die insbesondere die Schar der Kriminaltechniker echauffierte. Denn Coles Buch zeigt anhand einiger zeitgenössischer Fälle, dass sowohl die mit der Auswertung beschäftigten Maschinen als auch die Menschen Fehler machen (259-286). Technisch gesprochen produzieren sie falsche Negative und falsche Positive: Sie erkennen übereinstimmende Datensätze nicht bzw. sie ordnen irrtümlicherweise Abdrücke einander zu, die nicht identisch sind. Auch bei der DNA-Analyse erwiesen sich einige Labors als nicht zuverlässig genug.

Der historisch interessierte Leser, der in Coles Erzählung bis in die zweite Hälfte des 20. Jahrhunderts vorgedrungen ist, findet diese Analyse im Ergebnis wenig überraschend. Das spricht für Coles Beweisführung und seine erfolgreiche Historisierung des scheinbar Vertrau-

\footnotetext{
* Simon A. Cole, Suspect Identities. A History of Fingerprinting and Criminal Identification, 2. Aufl., Cambridge: Harvard University Press 2002 (erste Aufl. ebenda 200I), $400 \mathrm{~S}$., ISBN 0-674-0045 5-8
} 